\title{
Editorial
}

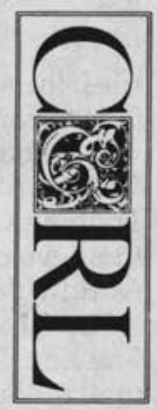

\section{To Marta: From the Drawer}

After the Soviet invasion several hundred writers were banished from official Czech literature. Unable to publish, some writers resigned themselves to writing for the drawer. Others, such as Ludvik Vaculik, began exchanging their manuscripts, frequently using feuilletons, short literary essays, to communicate. Some wrote regularly and used the feuilleton to comment on events both personal and general. The writings of these forbidden authors eventually gained wide currency. Some found their way abroad and later returned to Czech readers, thanks to émigré publishers.

On July 4, I began to read A Cup of Coffee with My Interrogator: The Prague Chronicles of Ludvik Vaculik (London: Readers International, 1987). In his introduction to this collection of Vaculik's writings, Vaclav Havel asks "To what extent has contemporary Czechoslovakia, and contemporary Central Europe, been cut off from the rest of the world? Or, in other words, to what extent are we today still able to understand one another?'

Naively, I thought of the problems central Europeans would have communicating with us but not the other way around, us with them.

The significance of Havel's question did not really hit me until I was reading the first piece by Vaculik, "Free to Use a Typewriter."

Vaculik, speaking to his fellow Czechs, asks "When did you last read anything interesting in the papers? By that I don't mean interesting reports about matters economic or technical, about natural phenomena or political revolutions, but an interesting idea on any of these subjects. You can progress along the road of discovery without anything really new being said until such time as someone gets a personal feeling about it and tries to put his thoughts into words."

I am not a Czech, but I understand. I know more than a few academic librarians who would say the same thing about library literature. Let us generalize. The same can be said for much of what we read, for as Vaculik goes on to say, "Ideas provide a language with inspiration, information exhausts it."

There is an obvious irony in the fact that more than 200 titles by forbidden Czech authors have appeared under the name of Padlock Publications. It may also be ironic that for us to understand contemporary central Europeans we must unlock our own thoughts, take them out of the drawer, and put them to the same kind of test that one must imagine forbidden authors or forbidden thoughts face throughout the world.

Vaculik's strength lies in his ability to enlighten not only his fellow Czechs but also others. We can understand one another only with difficulty and only if we are honest. And if we care.

Marta Dosa is a professor at the Syracuse University School of Information Studies. She received her doctorate from the University of Michigan. Her dissertation, since published, is about Georg Leyh, director of the Tübingen University Library from 1921 to 1947, a few years after the fall of the Third Reich. She is also the godmother of my son.

Marta is deeply interested in international affairs and has delivered scores of addresses throughout the world. She is devoted to linking countries, especially developing coun- 
tries, through information and people-sharing. She has an outstanding international reputation. For example, she was involved in efforts by the People's Republic of China to develop a national information policy.

Marta serves as chair of the International Federation for Documentation/Education and Training Committee (FID/ET). This committee promotes cooperation among nations for the development of education for the information professions; it links members of the worldwide information education community interested in sharing ideas and experience.

FID/ET also supports the International Clearinghouse of Information Education and Training. It serves as a source of educational and training materials for information educators, researchers, and policy makers. Course syllabi, reading lists, lecture notes, test problems, training packages, and audiovisual aids are included. Inquiries in all languages are welcome, and programs in the developing regions of the world receive special emphasis.

Last spring I learned of Marta's work with FID/ET. I wanted to help. I read the brochure and other material. Only words, I thought, abstract words.

I realized with a certain sadness that I didn't care.

However, the words of Vaculik, rather, the ideas of Vaculik opened up old memories in me, memories of a young man who joined the U.S. Army in January 1957. This act was taken, at least in part, to offer one small exception to the shallow words of support given by the American people to central European peoples striving in their own ways for more freedom.

Inquiries about the FID/ET International Clearinghouse of Information Education and Training can be sent to Marta Dosa, Professor, School of Information Studies, Syracuse University, Syracuse, NY 13210; (315) 423-4930.

\section{CHARLES MARTELL}

\section{IN FORTHCOMING ISSUES OF \\ COLLEGE \& RESEARCH LIBRARIES}

Fairness in Book Fund Allocation

by Jasper G. Schad

Tradition and Expertise in Collection Development by Lawrence Thomas

Coping with Pressures to Publish: Librarians and Faculty Members by Robert Boice and Jordan Scepanski

The Obstacles to Reform: China Modernizes Its University Libraries by Henrietta Lo

Material Availability: A Study of Academic Library Performance by Anne C. Ciliberti, Mary F. Casserly, Judith L. Hegg, and Eugene S. Mitchell

An In-House Training Program for Integrated Library Systems

by Stuart Glogoff and James P. Flynn 